\title{
Sensitivity analysis of the impact of part assignment in cellular manufacturing systems
}

\author{
Abdelghafour Al-Zawahreha, Nadia Dahmani ${ }^{\mathrm{b}, \mathrm{c}}$, Khaled Abu Alethem ${ }^{\mathrm{d}}$ and Adnan Mukattash $^{\mathrm{d}}$
}

aDepartment of Business Administration, Faculty of Economics and Administrative Sciences, Hashemite University, Zarqa Jordan ${ }^{b}$ LARODEC Laboratory, Institut Superieur de Gestion, 2000 Le Bardo, Tunisia

${ }^{c}$ Department of Management, Emirates College of Technology, Abu Dhabi, UAE

${ }^{d}$ Department of Industrial Management, Emirates College of Technology, Abu Dhabi, UAE

\section{H R O N I C L E}

Article history:

Received November 18, 2017

Received in revised format:

January 8, 2018

Accepted March 17, 2018

Available online

March 17, 2018

Keywords:

Cell formation

Part assignment

Optimal solution

Alternative optimal solution

Grouping measures

\begin{abstract}
A B S T R A C T
Optimality and efficiency are two measures that can be used by the system designer to select or compare between different optimal layouts. At the same time, the system designer has three choices of part assignment to cells in accordance with his needs (minimum sum of voids and /or exceptions). Unfortunately, the impact of choosing the type of part assignment on optimality and/or efficiency is not taken into consideration in any previous studies. In this paper, a critical analysis of the impact of part assignment in cellular manufacturing systems is elaborated on three cases borrowed from the literature. In the first case study, different grouping efficiency measures were used on two different optimal distributions having the same number of cells. These measures give different conflict evaluations, for that the designer's decision to choose the optimal solution depends on the optimality rather than the efficiency. For the second case, the analysis was performed using three types of part assignment on the same optimal system (same number of cells). The results showed that the designer's decisions depend on the constraints on the shop floor, since there is a conflict between the efficiency and the optimality. For the third case, one type of part assignment was executed on one system with different number of cells and the designer takes his decision based on the efficiency.
\end{abstract}

2019 by the authors; licensee Growing Science, Canada.

\section{Introduction}

Group technology (GT) can be stated as a manufacturing philosophy for improving productivity in batch production system (Srinivasan \& Narendran, 1991). Ho and Moodie (1996) defined cellular manufacturing $(\mathrm{CM})$ as a direct application of GT in which a manufacturing system is partitioned into subsystems. The first step in cell design is the cell formation. The primary objective of cell formation is to generate distinct machine clusters and part families. Cell formation tries to create cells (machine groups), where parts in each cell are deal with minimum interaction with other cells (Adil et al., 1996). GT problem uses a zero-one matrix $A$ where $\mathrm{a}_{\mathrm{ij}}=1$ represents the relationship between component $j$ to machine $i$, and $\mathrm{a}_{\mathrm{ij}}=0$, otherwise. When the components are divided into group families and machines are categorized into cells we may build a transformed matrix with diagonal blocks where ones located in the diagonal blocks and zeros are also located in the off-diagonal blocks. The resulted diagonal blocks represent the manufacturing cells.

* Corresponding author. Tel.: +971 506716172

E-mail address: adnan.muqatash@ect.ac.ae (A. Mukattash)

C 2019 by the authors; licensee Growing Science, Canada. doi: $10.5267 /$ j.dsl.2018.3.004 
The ideal situation appears when all the ones are in the diagonal blocks and all the zeros are located off the diagonal blocks (Nair \& Narendran, 1996 1998). However, this often does not happen in practice. Thus, the most attractive solution for CM systems is to have minimum number of zero entries inside a diagonal block and minimum number of ones entries outside the diagonal blocks (Suresh Kumar \& Chandrasekharan, 1990). Voids and exceptional elements have advance implications in terms of system operations (for more details see Adil et al., 1996). Some of the important characteristics of the GT problem are (Srivastava \& Chen, 1995) as follows,

1. Number of cells: The desired number of machine cells and/or part families can be specified a priori or determined by the solution approach a posteriori.

2. Cell size: To simplify managerial and control structures together with easier material coordination, the number of machines in each cell needs to be limited.

Specifying the number of cells in advance is a managerial decision. This decision is generally based on various factors such as total number of machines to be assigned to cells (cell size), physical constraints on the shop floor, and labor relation issues (Gupta et al., 1995). In his model (Del Valle et al., 1994), assumed that the maximum number of cells has to be established by the management. Crama and Oosten (1996) developed a model for machine-part grouping, with additional constrains in order to express limitations of a physical, technological or organizational nature. These limitations will be cardinality constrains on the size or the number of cells. Moreover, as the number of cells increases, material handling decreases. However, the number of bottleneck operations increases together with the investment by the management too (Sarker \& Balan, 1996). Some algorithms which do not impose any restriction on the cell size or the maximum number of cells, and try to reacg the natural grouping from the input matrix, will have some limitations since the quality of the solution depends on the initial machine clusters which are used (Viswanathan, 1996). The effectiveness of a solution is normally measured by its grouping efficiency (P Chandrasekharan \& Rajagopalan, 1986) or grouping efficacy (Suresh Kumar \& Chandrasekharan 1990) or the total number of voids in the diagonal blocks and the number of ones outside the blocks (Viswanathan, 1996).

The structure of the final machine-component matrix substantially influences on the effectiveness of the corresponding CM system (Seifoddini \& Djassemi, 1996). For this particular reason, the choice of grouping methodology has to be based on some criteria, which could indicate the goodness of a grouping solution. Therefore, a large number of grouping measures have been introduced to make an assessment on the efficiency of the block diagonal forms. The commonly known grouping efficiency measures in the literature are the Grouping efficiency ( $\boldsymbol{\eta}$ ) (P Chandrasekharan \& Rajagopalan, 1986), Grouping efficacy $(\tau)$ (Suresh Kumar and Chandrasekhoran, 1990), Grouping capability index (GCI) (Hsu, 1990), Global efficiency (GLE): (Harhalakis et al., 1990), Grouping measure (Miltenburg \& Zhang, 1991), Grouping Index $(\gamma)$ (Nair \& Narendran, 1996, 1998), Weighted Grouping Efficiency (Sarkar and Khan 2001 ) and Double weighted grouping efficiency (Sarkar 2001 ). Grouping Cell Index (Mukattash, 2003), Modified Grouping Efficacy measure (MGE), (Rajesh et al., 2016), Weighted Modified Grouping Efficacy (WMGE), (Al- Bashir et al., 2018), Comprehensive Grouping Efficacy (CGE) (Mukattash et al., 2018), Grouping Cell Indicator (GCI), (Al- Bashir et al., 2016). Weighted grouping efficacy $(\omega)$ : $(\mathrm{Ng}, 1993)$, Modified grouping efficacy $\left(\tau_{2}\right)$ : (Nair \& Narendran, 1996, 1998), Cell Utilization (CU): (Mahdavi et al., 2007) and Measure of Flexibility (MF): (Nagendra Parashar, 2004).

For other measures that are available in the literature (See Sarker, 1999; Sarker \& Khan, 2001; Sarker \& Khan, 2001; Keeling et al., 2007; Mukattash et al., 2018). According to Lee and Ahn (2013) GT can be used as a standard tool for assessing solutions based on a binary part-machine matrix without using the ordinal data. Keeling et al. (2007) pointed out that the quality of machine and part groupings could be evaluated using various objective functions, including grouping efficacy, grouping index, grouping capability index, and doubly weighted grouping efficiency. In addition, they developed a grouping genetic algorithm and reported that despite the fact that there are several studies on optimizing cell 
formations using efficiency measures, the cells which are formed this way do not always yield optimized factory measures. Since the GT problem has a multi-objective nature, various objectives have been proposed such as minimizing the number of inter-cell movements, the number or cost of machines duplicated, the number of exceptional parts, machine utilization imbalance, or maximizing summed similarities and machine utilization (for more details see Papaioannou \& Wilson, 2011).

From the above it can realize that, the first problem in cell formation is how to minimize the number of exceptional elements. If the designer wishes to form a cell regardless of the number of machines inside the cell, then the number of zeroes inside the cell (voids) will increase. For that the designer will face with two objectives of maximizing the utilization (by minimizing the zeroes inside the blocks) and minimizing the inter-cell movements (minimize ones outside the blocks) (P Chandrasekharan \& Rajagopalan, 1986). Next, part assignment is executed to minimize the number of voids and/or the number of exceptions. Cell size, labor relations, physical, technological, organizational, and economical constraints are factors that make it necessary to choose the type of part assignment. This means that there is a strong relationship between the type of part assignment and the constraints on the shop floor. In cell formation the system designer has three choices of part assignment to cells in accordance with his needs (minimum sum of voids and /or exceptions). The three choices of part assignment will give the designer the ability to reduce the effects of some of the physical, technological, or organizational constraints and hence reduces the transportation costs. Moreover, these choices will give him more flexibility to choose or compare between different optimal cells. Optimality of cellular manufacturing systems in cell formation can be achieved by finding all the possible ways of distribution of $n$-machines to $p$-cells with no cell empty.

In the literature, there are many researchers tried to study the relationship between the types of part assignment and other factors in cell formation (Rajamani et al., 1996; Adil et al., 1996; Chen \& Guerrero, 1994; Sarker \& Balan, 1996; Kusiak \& Cho, 1992; Chow \& Hawaleshka, 1993; Mukattash et al., 2002).

This paper introduces a sensitivity analysis for the impact of the type of part assignment using some of the well-known grouping efficiency measures in cellular manufacturing systems. The three choices of part assignment will give the designer the ability to reduce the effects of some of the physical, technological, or organizational constraints and hence reduces costs. The analysis shows that, the designer's decision to choose the optimal manufacturing system may not necessarily depend on the optimality and/or the efficiency of that system. For that, the effect of some constraints on the shop floor should be taken into consideration to help him in his decision.

\section{Commonly Known Grouping Efficiency Measures}

The following definitions will be used in this paper:

Block: A sub-matrix of the machine component incidence matrix formed by the intersection of columns representing a component family and rows representing a machine cell.

Voids (v): A zero element appearing in a diagonal block.

Exceptional element (or exception) (e): A one appearing in the off - diagonal blocks.

Perfect block-diagonal form: A block diagonal form in which all diagonal blocks contain ones and all off-diagonal blocks contain zeros. Kumar and Chandrasekhoran (1990)

Sparsity (Block diagonal space) (B): Total number of elements within the diagonal blocks of the solved matrix, (Sarker and Khan 2001).

Optimal solution: A system that contains minimum sum of voids and/or exceptions in the solved matrix.

Alternative optimal solution: Two or more optimal systems having same sum of voids and exceptions in the solved matrix.

The following grouping efficiency measures will be used to study the impact of the of part assignment in cellular manufacturing systems. 
According to P Chandrasekharan and Rajagopalan (1986) Grouping efficacy $(\tau)$ is defined as:

$$
\tau=\frac{1-\Psi}{1+\phi},
$$

where $\Psi=\frac{\text { Number of exceptional elements }}{\text { Total number of operations in the MP matrix }}$ and $\phi=\frac{\text { Number of voids in the diagonal blocks }}{\text { Total number of operations in the MP marix }}$.

$$
\tau=\frac{\mathrm{k}}{\mathrm{k}+v+\mathrm{e}_{0}}
$$

where $k+e$ is the total number of operations in the MP matrix, $k$ is the number of operations in the diagonal block, $e$ is the number of exceptions and finally, $v$ is the number of voids.

Accourding to Nair and Narendran (1996), Grouping Index $(\gamma)$ is defined as:

$$
\gamma=\frac{1-\frac{q e v+(1-q)\left(e_{0}-A\right)}{B}}{1+\frac{q e v+(1-q)\left(e_{0}-A\right)}{B}},
$$

where $A=0$ for $e 0 \leq B$ and $A=e 0-B$ for $e 0$ greater than $B$ can be written as follows,

$\gamma=\frac{1-\alpha}{1+\alpha}$, where $\quad \alpha=\frac{q e_{v}+(1-q)(e 0-A)}{B}$ and $\gamma=\frac{1-\alpha}{1+\alpha}$, where $\quad \alpha=\frac{q e_{v}+(1-q)(e 0-A)}{B}$ and A is a correction factor and $B$ is the sparsity of the solved matrix and $e_{0}$ is the number of exceptions, $e_{v}$ is the number of voids and $\mathrm{q}$ is the weighted factor. Moreover, Hsu (1990) defines Grouping Capability Index (GCI) as follows,

$$
G C I=1-\frac{e_{o}}{e}
$$

where

$\mathrm{e}_{\mathrm{o}}$ : number of exceptional elements in the machine-component matrix.

e: total number of one entries in the machine-component matrix.

\subsection{Impact of using different grouping efficiency measures on alternative optimal solutions}

Grouping efficiency measures are effective tools to evaluate the effectiveness of the structure of the final machine-component matrix in cellular manufacturing systems. In the following subsections the impact of using more than grouping measure on alternative optimal solutions will be studied and analyzed on two different case studies taken from the literature.

\section{Illustration 1-a}

The case study contains of 24 machines and 40 parts, taken from Nair and Narendran (1996). The following table summarizes the results.

Table 1

Evaluation of different measures

\begin{tabular}{ccccccccccc}
\hline $\begin{array}{c}\text { Optimal } \\
\text { solution }\end{array}$ & $\begin{array}{c}\text { \# of } \\
\text { cells }\end{array}$ & $\begin{array}{c}\text { Voids } \\
\text { (v) }\end{array}$ & $\begin{array}{c}\text { Exceptions } \\
\text { (e) }\end{array}$ & $\mathbf{v + e}$ & $\begin{array}{c}\text { Sparsity } \\
\text { (B) }\end{array}$ & $\begin{array}{c}\text { Total number of } \\
\text { operations in } \\
\text { the MP matrix }\end{array}$ & $\begin{array}{c}\text { \# of } \\
\text { operations } \\
\text { inside the } \\
\text { cells }\end{array}$ & $\begin{array}{c}\text { Grouping } \\
\text { Index }(\gamma),\end{array}$ & $\begin{array}{c}\text { Grouping } \\
\text { Efficacy }(\tau)\end{array}$ & $\begin{array}{c}\text { Grouping } \\
\text { capability } \\
\text { index }(\mathrm{GCI})\end{array}$ \\
\hline $\mathbf{1}^{\text {st }}$ & 7 & 7 & 19 & $\underline{\mathbf{2 6}}$ & 131 & 143 & 124 & $\mathbf{0 . 8 1 9 5}$ & $\mathbf{0 . 8 2 6 7}$ & $\mathbf{0 . 8 6 7}$ \\
$\mathbf{2}^{\text {nd }}$ & 7 & 19 & 7 & $\underline{\mathbf{2 6}}$ & 131 & 119 & 112 & $\mathbf{0 . 8 1 9 5}$ & $\mathbf{0 . 8 1 1 6}$ & $\mathbf{0 . 9 4 0}$ \\
\hline
\end{tabular}


Table 1 shows that number of cells, sparsity and sum of the voids and the exceptions are constant for the two solutions. Based on these measures the designer cannot choose the optimal or the best distribution between the two solutions $(\mathrm{v}+\mathrm{e}=26)$, since the three grouping measures give different conflicting evaluations. For Grouping Index $(\gamma)$, there is no difference between the two cells. For Grouping Efficacy $(\tau)$, the designer has to choose the first solutions (minimum voids). For grouping capability index (GCI), second solution has to be chosen (minimum exceptions). In other words the designer has to ignore these grouping measures and make his decision based on the optimality rather than the efficiency. In this situation where different grouping measures have been used for the two alternative optimal solutions, the designer's decision to choose one of them depends on his wish either to choose minimum voids or minimum exceptions.

\section{Illustration 1-b}

The case study contains of 6 machines and 6 parts (Fig.1), the problem was solved, using Kusiak's 1987 original p-median formulation and Viswanathan's 1996 revised p-median approach. The solution obtained using Kusiak's original p-median formulation and Viswanathan's revised p-median approach is given in Fig.2.

\begin{tabular}{|c|cccccc|}
\multicolumn{1}{c}{ machines } & $\mathbf{1}$ & $\mathbf{2}$ & $\mathbf{3}$ & $\mathbf{4}$ & $\mathbf{5}$ & $\mathbf{6}$ \\
\hline $\mathbf{1}$ & 0 & 1 & 0 & 1 & 0 & 1 \\
$\mathbf{2}$ & 1 & 0 & 0 & 1 & 1 & 0 \\
$\mathbf{3}$ & 1 & 0 & 0 & 0 & 1 & 0 \\
$\mathbf{4}$ & 0 & 1 & 1 & 0 & 0 & 0 \\
$\mathbf{5}$ & 0 & 0 & 1 & 0 & 0 & 1 \\
$\mathbf{6}$ & 0 & 1 & 0 & 1 & 0 & 0 \\
\hline
\end{tabular}

Fig. 1. Machine-part matrix for the numerical example

\begin{tabular}{c|c|cc|cc|cc|}
\hline \multirow{5}{*}{ machines } & \multicolumn{1}{c}{ Parts } & $\mathbf{5}$ & $\mathbf{2}$ & $\mathbf{4}$ & $\mathbf{3}$ & $\mathbf{6}$ \\
\hline $\mathbf{2}$ & 1 & 1 & 0 & 1 & 0 & 0 \\
$\mathbf{3}$ & 1 & 1 & 0 & 0 & 0 & 0 \\
\cline { 2 - 8 } & $\mathbf{1}$ & 0 & 0 & 1 & 1 & 0 & 1 \\
$\mathbf{6}$ & 0 & 0 & 1 & 1 & 0 & 0 \\
\hline $\mathbf{5}$ & 0 & 0 & 0 & 0 & 1 & 1 \\
$\mathbf{4}$ & 0 & 0 & 1 & 0 & 1 & 0 \\
\hline
\end{tabular}

Fig. 2. Solution for Kusiak's and Viswanathan's approach

The second optimal solution was solved by Mukattash (2000), using the 3-cell approach and the solution obtained is shown in Fig.3.

\begin{tabular}{c|c|cc|cc|cc|}
\hline & $\mathbf{1}$ & $\mathbf{5}$ & $\mathbf{2}$ & $\mathbf{4}$ & $\mathbf{3}$ & $\mathbf{6}$ \\
\hline $\mathbf{5}$ & 1 & 1 & 0 & 1 & 0 & 0 \\
machines & $\mathbf{3}$ & 1 & 1 & 0 & 0 & 0 & 0 \\
\cline { 2 - 8 } & $\mathbf{1}$ & 0 & 0 & 1 & 1 & 0 & 1 \\
$\mathbf{4}$ & 0 & 0 & 1 & 0 & 1 & 0 \\
$\mathbf{6}$ & 0 & 0 & 1 & 1 & 0 & 0 \\
\hline $\mathbf{5}$ & 0 & 0 & 0 & 0 & 1 & 1 \\
\hline
\end{tabular}

Fig. 3. Second optimal solution for Mukattash approach 
Table 2

Evaluation of different measures for Fig. 1(efficiency of block-diagonal form $)(\mathrm{q}=0.5)$

\begin{tabular}{ccccccccrr}
\hline Figure & $\begin{array}{c}\text { \# machines in } \\
1^{\text {st }} \text { cell }\end{array}$ & $\begin{array}{c}\text { \# machines } \\
\text { in } 2^{\text {nd }} \text { cell }\end{array}$ & $\begin{array}{c}\text { \# machines } \\
\text { in } 3^{\text {rd }} \text { cell }\end{array}$ & $\begin{array}{c}\text { \# parts in } \\
1^{\text {st }} \text { cell }\end{array}$ & $\begin{array}{c}\text { \# parts in } \\
2^{\text {nd }} \text { cell }\end{array}$ & $\begin{array}{c}\text { \# parts } \\
\text { in } 3^{\text {rd }} \\
\text { cell }\end{array}$ & $\mathbf{e}+\mathbf{v}$ & $\begin{array}{c}\tau \\
\text { Grouping } \\
\text { Efficacy }\end{array}$ & $\begin{array}{c}\mathbf{Y} \\
\text { Grouping } \\
\text { Index }\end{array}$ \\
\hline 2 & 2 & 2 & 2 & 2 & 2 & 2 & 4 & $\mathbf{0 . 7 3}$ & $\mathbf{0 . 7 1 4}$ \\
3 & 2 & 3 & 1 & 2 & 2 & 2 & 4 & $\mathbf{0 . 7 3}$ & $\mathbf{0 . 7 1 4}$ \\
\hline
\end{tabular}

Table 2 shows that the two grouping measures give the same results for both optimal solutions. For that the designer cannot take decision to choose one of these solutions based on grouping measures. In both cases (illustration 1-a and 1-b) his decision will be made based on optimality rather than efficiency.

\subsection{Impact of using different types of Part assignment on one optimal solution}

In order to study the impact of all types of part assignment on one optimal solution (distribution), we consider the matrix given in Fig. 4 taken from the literature (Pachayappan \& Panneerselvam, 2015). The system contains of five machines and seven parts. In order to find the optimal solution(s) of this system, different methods and algorithms from the literature will be used to form two, three and four optimal distributions (cells). The optimal solution can be achieved by finding all the possible ways to form two, three and four cells from five machines. Then part assignment will be performed to these distributions with minimum sum of voids and/or exceptions. Finally, grouping efficiency of these distributions can be found by using one of the well-known grouping measures called grouping efficacy.

\begin{tabular}{|c|ccccccc|}
\multicolumn{1}{c|}{ machines } \\
\multicolumn{1}{c|}{} & $\mathbf{1}$ & $\mathbf{2}$ & $\mathbf{3}$ & $\mathbf{4}$ & $\mathbf{5}$ & $\mathbf{6}$ & $\mathbf{7}$ \\
\hline $\mathbf{1}$ & 0 & 1 & 0 & 1 & 1 & 1 & 0 \\
$\mathbf{2}$ & 1 & 0 & 1 & 0 & 0 & 0 & 0 \\
$\mathbf{3}$ & 1 & 0 & 1 & 0 & 0 & 1 & 1 \\
$\mathbf{4}$ & 0 & 1 & 0 & 1 & 0 & 1 & 0 \\
$\mathbf{5}$ & 1 & 0 & 0 & 0 & 1 & 0 & 1 \\
\hline
\end{tabular}

Fig. 4. Machine-part matrix for the numerical example

\section{Cell Formation}

All possible ways to form 2-cells from 5- machines with no cell empty will be studied using the interactive algorithm developed by Mukattash et al. (2017). All the possible ways of forming the two cells are equal to 15 ways. Then part assignment will be accomplished to all these ways with minimum sum of voids and/or exceptions. Moreover, grouping efficacy will be used to find the efficiency of the fifteenth distributions.

From Table 3, it is clear that the second and the eighth distribution have the minimum exceptions ( $\mathrm{e}=2$ ). According to the definition of the optimality, both distributions are optimal. Having more than one optimal distribution will give the designer the flexibility to choose the most adequate one, so he can avoid some of the constraints on the shop floor. But according to the efficiency $(\tau)$, the designer will choose the eighth distribution which has the highest quality $(0.70)$. In this case the grouping measure of efficiency has different impacts on the same system having the same number of minimum exceptions. In both cases the optimal distributions have different values of efficiency $(0.51$ for the second distribution and 0.70 for the eighth distribution). In this case the designer decision will depend on the constraints on the shop floor, since there is a contradictory between efficiency and optimality. The optimal solution for both distributions are shown in Fig. 5 and Fig. 6. 
Table 3

All possible distributions to form 2-cells from 5-machines with minimum exceptions

\begin{tabular}{|c|c|c|c|c|c|c|c|c|c|}
\hline \# & $\begin{array}{c}\text { All possible } \\
\text { distributions with } \\
\text { minimum exceptions }\end{array}$ & $\begin{array}{c}\text { \# of } \\
\text { exceptions } \\
\text { (e) }\end{array}$ & $\begin{array}{l}\text { \# of } \\
\text { voids } \\
\text { (v) }\end{array}$ & $\mathrm{e}+\mathrm{v}$ & $\begin{array}{l}\text { Sparsity } \\
\text { (B) }\end{array}$ & $\begin{array}{l}\text { Total number } \\
\text { of operations in } \\
\text { the MP matrix }\end{array}$ & $\begin{array}{l}\text { \# of operations } \\
\text { inside the cells }\end{array}$ & $\begin{array}{l}\text { Grouping } \\
\text { Efficacy } \\
(\tau)\end{array}$ & $\begin{array}{c}\text { Optimality vs. } \\
\text { Efficiency }\end{array}$ \\
\hline 1 & $(\mathrm{~m} 1)(\mathrm{m} 2 \mathrm{~m} 3 \mathrm{~m} 4 \mathrm{~m} 5)$ & 4 & 7 & 11 & 19 & 16 & 12 & 0.52 & \\
\hline 2 & $(\mathrm{~m} 2)(\mathrm{m} 1 \mathrm{~m} 3 \mathrm{~m} 4 \mathrm{m5})$ & $\underline{2}$ & 11 & 13 & 25 & 16 & 14 & $\underline{0.51}$ & $\begin{array}{c}\text { First optimal } \\
\text { solution with } \\
\text { minimum } \\
\text { exceptions }(e=2)\end{array}$ \\
\hline 3 & $(\mathrm{~m} 3)(\mathrm{m} 1 \mathrm{~m} 2 \mathrm{~m} 4 \mathrm{~m} 5)$ & 4 & 10 & 14 & 22 & 16 & 12 & 0.46 & \\
\hline 4 & $(\mathrm{~m} 4)(\mathrm{m} 1 \mathrm{~m} 2 \mathrm{~m} 3 \mathrm{~m} 5)$ & 3 & 9 & 12 & 22 & 16 & 13 & 0.52 & \\
\hline 5 & $(\mathrm{~m} 5)(\mathrm{m} 1 \mathrm{~m} 2 \mathrm{~m} 3 \mathrm{~m} 4)$ & 3 & 9 & 12 & 22 & 16 & 13 & 0.52 & \\
\hline 6 & $(\mathrm{~m} 1 \mathrm{~m} 2)(\mathrm{m} 3 \mathrm{~m} 4 \mathrm{~m} 5)$ & 6 & 8 & 14 & 18 & 16 & 10 & 0.41 & \\
\hline 7 & $(\mathrm{~m} 1 \mathrm{~m} 3)(\mathrm{m} 2 \mathrm{~m} 4 \mathrm{~m} 5)$ & 7 & 8 & 15 & 17 & 16 & 9 & 0.37 & \\
\hline 8 & $(\mathrm{~m} 1 \mathrm{~m} 4)(\mathrm{m} 2 \mathrm{~m} 3 \mathrm{m5})$ & $\underline{2}$ & 4 & 6 & 18 & 16 & 14 & 0.70 & $\begin{array}{l}\text { Second optimal } \\
\text { solution with } \\
\text { minimum } \\
\text { exceptions }(\mathrm{e}=2) \\
\text { and the highest } \\
\text { efficiency }(\tau=0.7)\end{array}$ \\
\hline 9 & $(\mathrm{~m} 1 \mathrm{~m} 5)(\mathrm{m} 2 \mathrm{~m} 3 \mathrm{~m} 4)$ & 5 & 7 & 12 & 18 & 16 & 11 & 0.47 & \\
\hline 10 & $(\mathrm{~m} 1 \mathrm{~m} 2 \mathrm{~m} 3)(\mathrm{m} 4 \mathrm{~m} 5)$ & 6 & 7 & 13 & 17 & 16 & 10 & 0.43 & \\
\hline 11 & $(\mathrm{~m} 1 \mathrm{~m} 2 \mathrm{~m} 4)(\mathrm{m} 3 \mathrm{~m} 5)$ & 4 & 6 & 10 & 18 & 16 & 12 & 0.54 & \\
\hline 12 & $(\mathrm{~m} 1 \mathrm{~m} 2 \mathrm{~m} 5)(\mathrm{m} 3 \mathrm{~m} 4)$ & 6 & 7 & 13 & 17 & 16 & 10 & 0.43 & \\
\hline 13 & $(\mathrm{~m} 2 \mathrm{~m} 3)(\mathrm{m} 1 \mathrm{~m} 4 \mathrm{~m} 5)$ & 3 & 5 & 8 & 18 & 16 & 13 & 0.62 & \\
\hline 14 & $(\mathrm{~m} 2 \mathrm{~m} 4)(\mathrm{m} 1 \mathrm{~m} 3 \mathrm{~m} 5)$ & 5 & 8 & 13 & 19 & 16 & 11 & 0.45 & \\
\hline 15 & $(\mathrm{~m} 2 \mathrm{~m} 5)(\mathrm{m} 1 \mathrm{~m} 3 \mathrm{~m} 4)$ & 4 & 6 & 10 & 18 & 16 & 12 & 0.54 & \\
\hline
\end{tabular}

\begin{tabular}{|l|l|l|l|l|l|l|l|}
\hline \multicolumn{1}{|c|}{ Parts } \\
\hline 2 & 3 & 1 & 2 & 4 & 5 & 6 & 7 \\
\hline 1 & 1 & 1 & 0 & 0 & 0 & 0 & 0 \\
\hline 3 & 0 & 0 & 1 & 1 & 1 & 1 & 0 \\
\cline { 1 - 1 } 4 & 1 & 1 & 0 & 0 & 0 & 1 & 1 \\
\cline { 1 - 1 } 5 & 0 & 0 & 1 & 1 & 0 & 1 & 0 \\
& & 0 & 0 & 1 & 0 & 1 \\
\hline
\end{tabular}

Fig. 5. First optimal 2-cell solution with minimum exceptions

\begin{tabular}{|l|l|l|l|l|l|l|l|}
\multicolumn{10}{|c|}{ Parts } \\
\hline & 2 & 4 & 6 & 5 & 1 & 3 & 7 \\
\hline 1 & 1 & 1 & 1 & 1 & 0 & 0 & 0 \\
\hline 4 & 1 & 1 & 1 & 0 & 0 & 0 & 0 \\
\hline 2 & 0 & 0 & 0 & 0 & 1 & 1 & 0 \\
\hline 3 & 0 & 0 & 1 & 0 & 1 & 1 & 1 \\
\cline { 1 - 4 } 5 & 0 & 0 & 0 & 1 & 1 & 0 & 1 \\
\hline
\end{tabular}

Fig. 6. Second optimal 2-cell solution with minimum exceptions and highest efficiency

From Table 4, it is clear that the first and the eighth distribution have the minimum voids $(v=3)$. For that these distributions will be the optimal distributions among the fifteenth distributions. According to optimality the designer will choose the two distributions. According to efficiency $(\tau)$ the eighth distribution with $\tau=0.73$ will be chosen by the designer. In both cases the optimal distributions have different values of efficiency ( 0.37 for the first distribution and 0.73 for the eighth distribution). In this case the designer's decision depends on the constraints on the shop floor, since there is a contradiction between the efficiency and the optimality. Also in this case the grouping measure of efficiency has different impacts on the same system having the same number of minimum voids. The optimal solutions for both distributions are shown in Fig. 7 and Fig. 8. In this case the shop floor constraints will be taken into consideration to choose the most adequate distribution. 
Table 4

All possible distributions to form 2-cells from 5-machines with minimum voids

\begin{tabular}{|c|c|c|c|c|c|c|c|c|c|}
\hline$\#$ & $\begin{array}{c}\text { All possible } \\
\text { distributions with } \\
\text { minimum voids }\end{array}$ & $\begin{array}{c}\text { \# of } \\
\text { exceptions } \\
\text { (e) }\end{array}$ & $\begin{array}{l}\text { \# of } \\
\text { voids } \\
\text { (v) }\end{array}$ & $e+v$ & $\begin{array}{l}\text { Sparsity } \\
\text { (B) }\end{array}$ & $\begin{array}{l}\text { Total number } \\
\text { of operations in } \\
\text { the MP matrix }\end{array}$ & $\begin{array}{l}\text { \# of operations } \\
\text { inside the cells }\end{array}$ & $(\tau)$ & $\begin{array}{l}\text { Optimality vs. } \\
\text { Efficiency }\end{array}$ \\
\hline 1 & $(\mathrm{~m} 1)(\mathrm{m} 2 \mathrm{~m} 3 \mathrm{~m} 4 \mathrm{m5})$ & 9 & $\underline{\mathbf{3}}$ & 12 & 10 & 16 & 7 & $\underline{0.37}$ & $\begin{array}{c}\text { First optimal } \\
\text { solution with } \\
\text { minimum voids } \\
\quad(v=3)\end{array}$ \\
\hline 2 & $(\mathrm{~m} 2)(\mathrm{m} 1 \mathrm{~m} 3 \mathrm{~m} 4 \mathrm{~m} 5)$ & 11 & 5 & 16 & 10 & 16 & 5 & 0.23 & \\
\hline 3 & $(\mathrm{~m} 3)(\mathrm{m} 1 \mathrm{~m} 2 \mathrm{~m} 4 \mathrm{~m} 5)$ & 10 & 4 & 14 & 10 & 16 & 6 & 0.30 & \\
\hline 4 & $(\mathrm{~m} 4)(\mathrm{m} 1 \mathrm{~m} 2 \mathrm{~m} 3 \mathrm{~m} 5)$ & 10 & 4 & 14 & 10 & 16 & 6 & 0.30 & \\
\hline 5 & $(\mathrm{~m} 5)(\mathrm{m} 1 \mathrm{~m} 2 \mathrm{~m} 3 \mathrm{~m} 4)$ & 10 & 4 & 14 & 10 & 16 & 6 & 0.30 & \\
\hline 6 & $(\mathrm{~m} 1 \mathrm{~m} 2)(\mathrm{m} 3 \mathrm{~m} 4 \mathrm{~m} 5)$ & 6 & 7 & 13 & 17 & 16 & 10 & 0.43 & \\
\hline 7 & $(\mathrm{~m} 1 \mathrm{~m} 3)(\mathrm{m} 2 \mathrm{~m} 4 \mathrm{~m} 5)$ & 7 & 6 & 13 & 15 & 16 & 9 & 0.41 & \\
\hline 8 & $(\mathrm{~m} 1 \mathrm{~m} 4)(\mathrm{m} 2 \mathrm{~m} 3 \mathrm{~m} 5)$ & 2 & $\underline{3}$ & 5 & 17 & 16 & 14 & $\underline{0.73}$ & $\begin{array}{l}\text { Second optimal } \\
\text { solution with } \\
\text { minimum voids } \\
(v=3) \text { and highest } \\
\text { efficiency }(\tau=0.73)\end{array}$ \\
\hline 9 & $(\mathrm{~m} 1 \mathrm{~m} 5)(\mathrm{m} 2 \mathrm{~m} 3 \mathrm{~m} 4)$ & 6 & 6 & 12 & 16 & 16 & 10 & 0.45 & \\
\hline 10 & $(\mathrm{~m} 1 \mathrm{~m} 2 \mathrm{~m} 3)(\mathrm{m} 4 \mathrm{~m} 5)$ & 6 & 7 & 13 & 17 & 16 & 10 & 0.43 & \\
\hline 11 & $(\mathrm{~m} 1 \mathrm{~m} 2 \mathrm{~m} 4)(\mathrm{m} 3 \mathrm{~m} 5)$ & 6 & 6 & 12 & 16 & 16 & 10 & 0.45 & \\
\hline 12 & $(\mathrm{~m} 1 \mathrm{~m} 2 \mathrm{~m} 5)(\mathrm{m} 3 \mathrm{~m} 4)$ & 6 & 6 & 12 & 16 & 16 & 10 & 0.45 & \\
\hline 13 & $(\mathrm{~m} 2 \mathrm{~m} 3)(\mathrm{m} 1 \mathrm{~m} 4 \mathrm{~m} 5)$ & 3 & 5 & 8 & 18 & 16 & 13 & 0.62 & \\
\hline 14 & $(\mathrm{~m} 2 \mathrm{~m} 4)(\mathrm{m} 1 \mathrm{~m} 3 \mathrm{~m} 5)$ & 6 & 7 & 13 & 17 & 16 & 10 & 0.43 & \\
\hline 15 & $(\mathrm{~m} 2 \mathrm{~m} 5)(\mathrm{m} 1 \mathrm{~m} 3 \mathrm{~m} 4)$ & 4 & 5 & 9 & 17 & 16 & 12 & 0.57 & \\
\hline
\end{tabular}

Parts

\begin{tabular}{|c|c|c|c|c|c|c|c|}
\hline & 2 & 3 & 4 & 5 & 6 & 7 & 1 \\
\hline 1 & 1 & 0 & 1 & 1 & 1 & 0 & 0 \\
\hline 2 & 0 & 1 & 0 & 0 & 0 & 0 & 1 \\
\hline 3 & 0 & 1 & 0 & 0 & 1 & 1 & 1 \\
\hline 4 & 1 & 0 & 1 & 0 & 1 & 0 & 0 \\
\hline 5 & 0 & 0 & 0 & 1 & 0 & 1 & 1 \\
\hline
\end{tabular}

Fig. 7. First optimal 2-cell solution with minimum voids

\begin{tabular}{|l|l|l|l|l|l|l|l|}
\hline & 2 & 4 & 5 & 6 & 1 & 3 & 7 \\
\hline 1 & 1 & 1 & 1 & 1 & 0 & 0 & 0 \\
\hline 4 & 1 & 1 & 0 & 1 & 0 & 0 & 0 \\
\hline 2 & 0 & 0 & 0 & 0 & 1 & 1 & 0 \\
\hline 3 & 0 & 0 & 0 & 1 & 1 & 1 & 1 \\
\hline 5 & 0 & 0 & 1 & 0 & 1 & 0 & 1 \\
\hline
\end{tabular}

Fig. 8. Second optimal 2-cell solution with minimum voids and highest efficiency

From Table 5, it is clear that there is one optimal solution with $(\mathrm{e}+\mathrm{v}=5)$ and the efficiency of the system is 0.73 . The optimal solution is shown in Fig. 9.

Table 5

Optimal solution with minimum sum of voids and exceptions

\begin{tabular}{|c|c|c|c|c|c|c|c|c|c|}
\hline \# & $\begin{array}{c}\text { Optimal solution } \\
\text { from all possible } \\
\text { distributions to form } \\
\text { 2-cells from 5- } \\
\text { machinews with } \\
\text { minimum sum of } \\
\text { voids and exceptions }\end{array}$ & $\begin{array}{c}\text { \# of } \\
\text { exceptions } \\
\text { (e) }\end{array}$ & $\begin{array}{l}\text { \# of } \\
\text { voids } \\
\text { (v) }\end{array}$ & $\mathrm{e}+\mathrm{v}$ & $\begin{array}{l}\text { Sparsity } \\
\text { (B) }\end{array}$ & $\begin{array}{l}\text { Total number of } \\
\text { operations in } \\
\text { the MP matrix }\end{array}$ & $\begin{array}{l}\text { \# of operations } \\
\text { inside the cells }\end{array}$ & $(\tau)$ & Optimal solution \\
\hline & $(\mathrm{m} 1 \mathrm{~m} 4)(\mathrm{m} 2 \mathrm{~m} 3 \mathrm{~m} 5)$ & 2 & 3 & $\underline{5}$ & 17 & 16 & 14 & $\underline{0.73}$ & $\begin{array}{l}\text { Optimal solution with } \\
\text { minimum sum of } \\
\text { voids and exceptions } \\
(\mathrm{e}+\mathrm{v}=5) \text { and highest }\end{array}$ \\
\hline & & & & & & & & & $\begin{array}{c}\text { efficiency }(\tau= \\
0.73)\end{array}$ \\
\hline
\end{tabular}




\begin{tabular}{|l|l|l|l|l|l|l|l|}
\hline \multicolumn{1}{|c|}{ Parts } \\
\hline 1 & 2 & 4 & 5 & 6 & 1 & 3 & 7 \\
\hline 4 & 1 & 1 & 1 & 1 & 0 & 0 & 0 \\
\hline 2 & 0 & 1 & 0 & 1 & 0 & 0 & 0 \\
\hline 3 & 0 & 0 & 0 & 0 & 1 & 1 & 0 \\
\hline 5 & 0 & 0 & 1 & 0 & 1 & 0 & 1 \\
\hline
\end{tabular}

Fig. 9. Optimal 2-cell solution with minimum sum of voids and exceptions

Using the three types of part assignment on the same system (two cells- with alternative optimal solutions) (Table 3, 4 and 5), the designer has three options of optimal manufacturing distributions. These options will give him more flexibility to avoid more constraints on the shop floor. Moreover, it is clear that the choice of part assignment may change the efficiency of the optimal solution. The impact of different types of part assignment (minimum sum of exceptions and/ voids) for the same system with different optimal cell layouts will change the designer's decision. While choosing one type of part assignment for alternative optimal solution (same cell size) may lead to us to face with some conflict between the optimality and the efficiency (Table 3 and 4 and related Figs. 5-8). In this case, the designer's decision will be based on the constraint on the shop floor.

\subsection{Impact of using one type of part assignment on different optimal distributions}

In order to study and analyze the effect of using one type of part assignment (minimum sum of voids and exceptions) on different optimal distributions of the same system, the same problem in Fig. 4. is solved to form 3-cells and 4-cells from 5-machines.

\section{Cell Formation}

From the literature, any method can be used to find all the possible distributions to form 3-cells from 5-machines with no cell empty. Then part assignment was done with minimum sum of voids and exceptions as shown below in Table 6. The optimal solution is shown in Figure 10.

Table 6

Optimal solution with minimum sum of voids and exceptions

\begin{tabular}{|c|c|c|c|c|c|c|c|c|c|}
\hline \# & $\begin{array}{l}\text { Optimal solution from } \\
\text { all possible } \\
\text { distributions to form } \\
\text { 3-cells from 5- } \\
\text { machinews with } \\
\text { minimum sum of } \\
\text { voids and exceptions }\end{array}$ & $\begin{array}{c}\text { \# of } \\
\text { exceptions } \\
\text { (e) }\end{array}$ & $\begin{array}{l}\text { \# of } \\
\text { voids } \\
\text { (v) }\end{array}$ & $\mathrm{e}+\mathrm{v}$ & $\begin{array}{l}\text { Sparsity } \\
\text { (B) }\end{array}$ & $\begin{array}{c}\text { Total number of } \\
\text { operations in the } \\
\text { MP matrix }\end{array}$ & $\begin{array}{l}\text { \# of operations } \\
\text { inside the cells }\end{array}$ & $(\tau)$ & $\begin{array}{l}\text { Optimal } \\
\text { solution }\end{array}$ \\
\hline & $(\mathrm{m} 2 \mathrm{~m} 3)(\mathrm{m} 1 \mathrm{~m} 4)(\mathrm{m} 5)$ & 4 & 0 & 4 & 12 & 16 & 12 & 0.75 & Optimal \\
\hline
\end{tabular}

\begin{tabular}{|c|c|c|c|c|c|c|c|}
\hline \multicolumn{8}{|c|}{ Parts } \\
\hline & 1 & 3 & 2 & 4 & 6 & 5 & 7 \\
\hline 2 & 1 & 1 & 0 & 0 & 0 & 0 & 0 \\
\hline 3 & 1 & 1 & 0 & 0 & 1 & 0 & 1 \\
\hline 1 & 0 & 0 & 1 & 1 & 1 & 1 & 0 \\
\hline 4 & 0 & 0 & 1 & 1 & 1 & 0 & 0 \\
\hline 5 & 1 & 0 & 0 & 0 & 0 & 1 & 1 \\
\hline
\end{tabular}

Fig. 10. Optimal 3-cell solution with minimum sum of voids and exceptions

\section{Cell Formation}

In the same way the same problem in Fig. 1 has been solved to form 4-cells from 5-machines using any method from the literature as shown in Table 7. The optimal solution is shown in Fig. 11. 
Table 7

Optimal solution with minimum sum of voids and exceptions

\begin{tabular}{|c|c|c|c|c|c|c|c|c|c|c|c|c|}
\hline \# & $\begin{array}{l}\text { Optimal solution from } \\
\text { all possible distributions } \\
\text { to form 4-cells from 5- } \\
\text { machinews with } \\
\text { minimum sum of voids } \\
\text { and exceptions }\end{array}$ & $\begin{array}{c}\text { \# of } \\
\text { exceptions } \\
\text { (e) }\end{array}$ & $\begin{array}{l}\text { \# of } \\
\text { voids } \\
\text { (v) }\end{array}$ & $\mathrm{e}+\mathrm{v}$ & \multicolumn{2}{|c|}{$\begin{array}{l}\text { Sparsity } \\
\text { (B) }\end{array}$} & \multicolumn{2}{|c|}{$\begin{array}{l}\text { Total number of } \\
\text { operations in the } \\
\text { MP matrix }\end{array}$} & \multicolumn{2}{|r|}{$\begin{array}{l}\text { \# of operations } \\
\text { inside the cells }\end{array}$} & $(\tau)$ & $\begin{array}{l}\text { Optimal } \\
\text { solution }\end{array}$ \\
\hline & $(\mathrm{m} 2)(\mathrm{m} 3)(\mathrm{m} 1 \mathrm{~m} 4)(\mathrm{m} 5)$ & 6 & 0 & $\underline{6}$ & \multicolumn{2}{|c|}{10} & \multicolumn{2}{|c|}{16} & & 10 & 0.62 & Optimal \\
\hline & & \multicolumn{8}{|c|}{ Parts } & & & \\
\hline & & & 1 & 3 & 7 & 2 & 4 & 6 & 5 & & & \\
\hline & & & 1 & 1 & 0 & 0 & 0 & 0 & 0 & & & \\
\hline & & & 1 & 1 & 1 & 0 & 0 & 1 & 0 & & & \\
\hline & & & 0 & 0 & 0 & 1 & 1 & 1 & 1 & & & \\
\hline & & & 0 & 0 & 0 & 1 & 1 & 1 & 0 & & & \\
\hline & & & 1 & 0 & 1 & 0 & 0 & 0 & 1 & & & \\
\hline
\end{tabular}

Fig. 11. Optimal 4-cell solution with minimum sum of voids and exceptions

From Table 5, 6 and 7, the system designer can choose between different optimal cells layout. The selection between these layouts is based on the efficiency. In this case he may choose the three cell formation with the efficiency equal to 0.75 . It is clear that, the impact of the same type of part assignment (minimum sum of voids and exceptions) on the same system with different number of cells is different for each layout. For that, the choice of the most adequate solution among these optimal distributions may depend totally on efficiency.

\section{Discussion and Conclusion}

Optimal cell solutions can be reached by finding all possible ways to form $n$-distinguishable machines into $p$-indistinguishable cells with no empty cell. All these possible ways will give the designer the flexibility of choosing the machine(s) inside the cell. In this paper, the impact of part assignment in cellular manufacturing systems has been studied for three case studies. The three cases have shown that the system designer cannot depend totally on optimality and/or efficiency as an effective tool to choose or compare between alternative optimal solutions. This is due to the conflicting objectives between optimality and efficiency. Moreover, the choice of the type of part assignment has a big impact on the manufacturing systems. In general the analysis of the impact of part assignment in cellular manufacturing systems has shown that:

- Alternative optimal solutions will give the designer more flexibility and in this case he can control the cell size and avoid the effects of some constraints on the shop floor.

- Using different grouping efficiency measures at the same time will make the designer more confused in taking his decision.

- The constraints on the shop floor will force the designer to choose the type of part assignment.

- Contradictory between the optimality and the efficiency in cellular manufacturing systems will make the designer more confused and in this case the type of part assignment and the constraints on the shop floor will be an effective tool to help him.

\section{References}

Adil, G. K., Rajamani, D., \& Strong, D. (1996). Cell formation considering alternate routeings. International Journal of Production Research, 34(5), 1361-1380.

Al-Bashir, A., Mukattash, A., Dahmani, N., \& Al-Abed, N. (2018). Critical analysis of modified grouping efficacy measure; new weighted modified grouping efficiency measure. Production \& Manufacturing Research, 6(1), 113-125. 
Al-Bashir, A. A., Mukattash, A. M., Muqattash, R. S., Al-Tal, S. Y., \& Qamar, A. M. (2016). Grouping Cell Indicator: A Modified Cell Formation Grouping Measure. Middle-East Journal of Scientific Research, 24(7), 2309-2320.

Chen, H. G., \& Guerrero, H. H. (1994). A general search algorithm for cell formation in group technology. The International Journal of Production Research, 32(11), 2711-2724.

Chow, W. S., \& Hawaleshka, O. (1993). Minimizing intercellular part movements in manufacturing cell formation. The International Journal of Production Research, 31(9), 2161-2170.

Crama, Y., \& Oosten, M. (1996). Models for machine-part grouping in cellular manufacturing. International Journal of Production Research, 34(6), 1693-1713.

Del Valle, A. G., Balarezo, S., \& Tejero, J. (1994). A heuristic workload-based model to form cells by minimizing intercellular movements. The International Journal of Production Research, 32(10), 2275-2285.

Gupta, Y. P., Gupta, M. C., Kumar, A., \& Sundram, C. (1995). Minimizing total intercell and intracell moves in cellular manufacturing: a genetic algorithm approach. International Journal of computer integrated manufacturing, 8(2), 92-101.

Harhalakis, G., Nagi, R., \& Proth, J. M. (1990). An efficient heuristic in manufacturing cell formation for group technology applications. The International Journal of Production Research, 28(1), 185198.

Ho, Y. C., \& Moodie, C. L. (1996). Solving cell formation problems in a manufacturing environment with flexible processing and routeing capabilities. International Journal of Production Research, 34(10), 2901-2923.

Hsu, C.P. (1990). Similarity coefficient approaches to machine-component cell formation in cellular manufacturing: a comparative study. PhD thesis,Industrial and Systems Engineering, University of Wisconsin-Milwaukee.

Keeling, K. B., Brown, E. C., \& James, T. L. (2007). Grouping efficiency measures and their impact on factory measures for the machine-part cell formation problem: A simulation study. Engineering Applications of Artificial Intelligence, 20(1), 63-78.

Kusiak, A. (1987). The generalized group technology concept. International journal of production research, 25(4), 561-569.

Kusiak, A., \& Cho, M. (1992). Similarity coefficient algorithms for solving the group technology problem. The International Journal Of Production Research, 30(11), 2633-2646.

Lee, K., \& Ahn, K. I. (2013). GT efficacy: a performance measure for cell formation with sequence data. International Journal of Production Research, 51(20), 6070-6081.

Mahdavi, I., Javadi, B., Fallah-Alipour, K., \& Slomp, J. (2007). Designing a new mathematical model for cellular manufacturing system based on cell utilization. Applied Mathematics and Computation, 190(1), 662-670.

Miltenburg, J., \& Zhang, W. (1991). A comparative evaluation of nine well-known algorithms for solving the cell formation problem in group technology. Journal of operations management, 10(1), 44-72.

Mukattash, A. M., Tahboub, K. K., \& Adil, M. B. (2017). Interactive design of cellular manufacturing systems, optimality and flexibility. International Journal on Interactive Design and Manufacturing (IJIDeM), 1-8.

Mukattash, A. (2003). Grouping Cell Index : A Modified Cell Formation Grouping Measure. Proceedings of the 31 st International Conference on Computers and Industrial Engineering, San Francesco, USA.

Mukattash, A. M., Adil, M. B., \& Tahboub, K. K. (2002). Heuristic approaches for part assignment in cell formation. Computers \& industrial engineering, 42(2-4), 329-341.

Mukattash, A., Dahmani, N., Al-Bashir, A., \& Qamar, A. (2018). Comprehensive grouping efficacy: A new measure for evaluating block-diagonal forms in group technology. International Journal of Industrial Engineering Computations, 9(1), 155-172. 
Nair, G. J. K., \& Narendran, T. T. (1996). Grouping index: a new quantitative criterion for goodness of block-diagonal forms in group technology. International Journal of Production Research, 34(10), 2767-2782.

Nair, G. J., \& Narendran, T. T. (1998). CASE: A clustering algorithm for cell formation with sequence data. International journal of production research, 36(1), 157-180.

Nagendra Parashar, B.S. (2004), Evaluation of cellular manufacturing systems design- VEDO Analysis, Industrial Engineering Journal, 33(6),pp.4-8.

$\mathrm{Ng}$, S. M. (1993). Worst-case analysis of an algorithm for cellular manufacturing. European Journal of Operational Research, 69(3), 384-398.

Papaioannou, G., \& Wilson, J. M. (2010). The evolution of cell formation problem methodologies based on recent studies (1997-2008): Review and directions for future research. European journal of operational research, 206(3), 509-521.

Pachayappan, M., \& Panneerselvam, R. (2015). Hybrid genetic algorithm for machine-component cell formation. Intelligent Information Management, 7(03), 107.

P Chandrasekharan, M., \& Rajagopalan, R. (1986). An ideal seed non-hierarchical clustering algorithm for cellular manufacturing. International Journal of Production Research, 24(2), 451-463.

Rajesh, K. D., Chalapathi, P. V., Chaitanya, A. B. K., Sairam, V., \& Anildeep, N. (2006). Modified grouping efficacy and new average measure of flexibility: performance measuring parameters for cell formation applications. ARPN Journal of Engineering and Applied Sciences, 11(15), 92129215.

Rajamani, D., Singh, N., \& Aneja, Y. P. (1996). Design of cellular manufacturing systems. International journal of production research, 34(7), 1917-1928.

Sarker, B. R., \& Balan, C. V. (1996). Cell formation with operation times of jobs for even distribution of workloads. International Journal of Production Research, 34(5), 1447-1468.

Sarker, B. R. (1999). Grouping efficiency measures in cellular manufacturing: a survey and critical review. International Journal of Production Research, 37(2), 285-314.

Sarker, B. R. (2001). Measures of grouping efficiency in cellular manufacturing systems. European Journal of Operational Research, 130(3), 588-611.

Sarker, B. R., \& Balan, C. V. (1996). Cell formation with operation times of jobs for even distribution of workloads. International Journal of Production Research, 34(5), 1447-1468.

Sarker, B. R., \& Khan, M. (2001). A comparison of existing grouping efficiency measures and a new weighted grouping efficiency measure. Iie Transactions, 33(1), 11-27.

Seifoddini, H., \& Djassemi, M. (1996). A new grouping measure for evaluation of machine-component matrices. International Journal of Production Research, 34(5), 1179-1193.

Srinivasan, G., \& Narendran, T. T. (1991). GRAFICS - a nonhierarchical clustering algorithm for group technology. The International Journal of Production Research, 29(3), 463-478.

Srivastava, B., \& Chen, W. H. (1995). Efficient solution for machine cell formation in group technology. International Journal of Computer Integrated Manufacturing, 8(4), 255-264.

Suresh Kumar, C., \& Chandrasekharan, M. P. (1990). Grouping efficacy: a quantitative criterion for goodness of block diagonal forms of binary matrices in group technology. International Journal of Production Research, 28(2), 233-243.

Viswanathan, S. (1995). Configuring cellular manufacturing systems: a quadratic integer programming formulation and a simple interchange heuristic. The International Journal of Production Research, 33(2), 361-376.

Viswanathan, S. (1996). A new approach for solving the P-median problem in group technology. International Journal of Production Research, 34(10), 2691-2700.

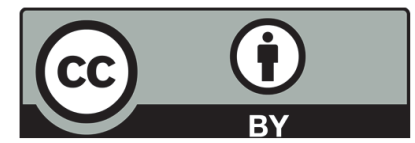

(C) 2019 by the authors; licensee Growing Science, Canada. This is an open access article distributed under the terms and conditions of the Creative Commons Attribution (CC-BY) license (http://creativecommons.org/licenses/by/4.0/). 